\title{
Carta a Elisée Reclus *1
}

(Tradução de Plínio Augusto Coelho)

Meu muito caro amigo. Agradeço-te muito por tuas boas palavras. Jamais duvidei de tua amizade, este sentimento é sempre mútuo, e eu julgo o teu em relação ao meu.

Sim, tens razão, a revolução no momento foi ao leito, recaímos no período das evoluções, quer dizer, naquele das revoluções subterrâneas, invisíveis e freqüentemente mesmo insensíveis. A evolução de hoje é muito perigosa, se não para a humanidade, pelo menos para certas nações. É a última encarnação de uma classe esgotada, jogando seu último jogo, sob a proteção da ditadura militar macmahono-bonapartista na França, bismarckiana no resto da Europa.

Eu concordo contigo em dizer que a hora da revolução passou, não por causa dos horrorosos desastres dos quais fomos testemunhas e das terríveis derrotas das quais fomos vítimas culpadas, mas porque, para meu grande desespero, constatei e constato todos os dias que o pensamento, a esperança e a paixão revolucionários não se encontram absolutamente nas massas, e quando elas estão ausentes, de nada vale fazer esforços inúteis. Admiro a paciência e a perseverança heróicas dos jurassianos e dos belgas - estes últimos moicanos da falecida Internacional - e que, apesar de todas as dificuldades, adversidades, apesar de todos os obstáculos, no meio da indiferença geral, opõem sua fonte obstinada ao curso absolutamente contrário das coisas, continuando a fazer tranquiilamente o que eles fizeram antes das catástrofes, quando o movimento geral era ascendente e o mínimo esforço criava uma força. Trabalho ainda mais meritório, visto que não colherão os frutos, mas eles podem estar certos de que

* Lugano, I5 de fevereiro de 1875. Archives Bakounine, Tomo V. op-pp. LXXXIII - LXXXIV.

I. Esta carta de Bakunin, escrita cinco anos após a derrota da Comuna de Paris, é dirigida ao seu companheiro de luta, o anarquista e geógrafo Elisée Reclus, autor de Nouvelle Géographie Universelle: la Terre et les Hommes e de um livro sobre o Brasil: Estados Unidos do Brasil - Geografia, Ethnografia, Estatistica de 1899. Apresenta o velho militante descrente das possibilidades de revolução e de organização das massas, mas completamente consciente de suas responsabilidades sociais, ao redirecionar sua forma de luta. Bakunin, como Kropotkin e como o próprio Reclus ao final da vida, dedicou-se à escrita. Nesta carta que publicamos, é forçoso destacar a enorme lucidez na previsão dos episódios que marcariam o século $X X$, as duas guerras mundiais.

Agradecemos a cessão de direitos da tradução - além da cuidadosa revisão - gentilmente feita por Plínio Augusto Coelho. 
o trabalho não será perdido - nada se perde neste mundo - e as gotas de água, por serem invisíveis, nem por isso deixam de formar o oceano.

Quanto a mim, meu caro, tornara-me muito velho, muito doente, muito desencorajado, e, devo te dizer, sob muitos pontos de vista muito desiludido, para sentir o desejo e a força de participar desta obra.

Eu decididamente me retirei da luta e passarei o resto de meus dias numa contemplação não desocupada, bem ao contrário, intelectualmente bem ativa, e que, espero, não deixará de produzir alguma coisa de útil.

Uma das paixões que me domina, neste momento, é uma imensa curiosidade. Uma vez que tive de reconhecer que o mal triunfou e que não pude impedilo, pus-me a estudar suas evoluçôes e seus desenvolvimentos com uma paixão quase científica, completamente objetiva.

Que atores e que cena. No fundo, e dominando toda a situação na Europa, estão o imperador Guilherme e Bismark, à frente de um grande povo lacaio. Contra eles, o papa, com seus jesuítas, com toda a Igreja católica e romana, ricos em bilhões, dominam uma grande parte do mundo através das mulheres, pela ignorância das massas, e pela habilidade incomparável de seus inúmeros filiados, tendo seus olhos e suas mãos em todos os lugares.

Terceiro ator - A civilização francesa, encarnada em Mac-Mahon, Dupanloup e Broglie, colocando as correntes em um grande povo em declínio. E em torno de tudo isso, a Espanha, a Itália, a Áustria e a Rússia, fazendo cada uma suas caretas de ocasião, e de longe a Inglaterra, não podendo se decidir a voltar a ser alguma coisa, e ainda mais longe, a República modelo dos Estados Unidos da América, já se engraçando com a ditadura militar.

Pobre humanidade!

É evidente que ela só poderá sair desta cloaca por uma imensa revolução social. Mas como ela fará esta revolução? Nunca a reação internacional da Europa esteve tão formidavelmente armada contra todo movimento popular. Ela fez da repressão uma nova ciência que se ensina sistematicamente nas escolas militares aos tenentes de todos os países. E para atacar esta fortaleza inexpugnável, o que temos? As massas desorganizadas. Mas como organizá-las quando elas não são suficientemente apaixonadas por sua própria salvação, quando não sabem o que devem querer e quando não querem a única coisa que pode salvá-las.

Resta a propaganda, tal como a fazem os jurassianos e os belgas. É alguma coisa sem dúvida, mas muito pouca coisa, algumas gotas de água no oceano; e se não houvesse outro meio de salvação, a humanidade teria tido tempo de apodrecer dez vezes antes de ser salva.

Resta uma outra esperança: a guerra universal. Estes imensos Estados militares que devem se entredestruir e se entredevorar, cedo ou tarde. Mas que perspectiva!

o manuscrito interrompe-se aqui (Nota do Tradutor) 